\title{
Herbal Tea Formulation for Health Rejenuvation: Nutritional, Physicochemical and Sensory Analysis
}

\author{
S J Kabilan, R Baskar, G Poorani
}

\begin{abstract}
The aim of the study were to perform nutritional, phytochemical and sensory analysis and assessing the potential of herbal formulation made up of Wedeliachinensis leaves and Boerhaaviadiffusa roots in possessing phytochemical contents and to be a part of herbal tea development. The phytochemical analysis were performed for each herb sample to determine the total phenolics, total flavanoids, crude alkaloids, tannins and identification of phytoconstituents such as phytosterol, coumarin, terpenoids, anthraquinone and phlobatannins. As part of nutritional analysis, tests such as moisture content, ash content and mineral composition of the herbal formulation mixture were performed. GC/MS screening was performed to check the presence of several effective compounds which indicated that selected sample holds the potential to be stated under "Nutraceuticals". Formulation of herbal tea with the selected herbs was made and sensory analysis performed to validate the aroma, colour, astringency, flavor and overall acceptability as an herbal tea. The results of the nutritional, phytochemical showed that the formulation mixture of herbs Wedeliachinensis and Boerhaaviadiffusa roots is an excellent source of nutraceuticals with high therapeutical importance. Multiple beneficial phytochemical content featured in this polyherbal formulation, makes it as a perfect physical and psychological health rejuvenator.
\end{abstract}

Keywords: Boerhaaviadiffusa, Polyherbal formulation, tisanes, Wedeliachinensis.

\section{INTRODUCTION}

Herbal teas are normally mixtures of multiple ingredients, and are more precisely known as 'tisanes'. Tisanes are combinations of dried leaves, grasses, seeds, nuts, fruits, barks, flowers, or other botanical elements which gives them their unique taste and the potentials of health benefits. Most of the herbal teas usually consist of one main herbal ingredient or a blend of herbal ingredients, promised to provide a specific purpose, such as rejuvenation or relief from a specific condition [16].

Wedeliachinensis (Manjalkarisalankanni in Tamil), Asteraceae is a highly regarded herbal medicine in Siddha, Unani and Ayurvedic system of medicine [5]. Extensive studies shows presence of flavanoids, diterpenes, triterpenes

Revised Manuscript Received on December 16, 2019

* Correspondence Author

S J Kabilan*, Department of Biotechnology,Kalasalingam Academy of Research and Education, Krishnankoil, Tamilnadu, India. Email: sjkabil@gmail.com

R Baskar, Department of Biotechnology, Kumaraguru College of Technology, Coimbatore, India. Email:baskar.r.bt@kct.ac.in

G Poorani, Department of Biotechnology, Kumaraguru College of Technology, Coimbatore, India. Email: gpoorani.biotech@gmail.com saponins and phytosteroids [6]. It is also reported to possess antioxidant, analgesic, anti-inflammatory, antimicrobial, CNS depressant,hepatoprotective, wound healing, antistress and anticancer activity $[8,18]$.

Boerhaaviadiffusa (Mookirattaikeerai in Tamil) is one among the well known medicinal plants that are used to treat huge multiple human diseased conditions as mentioned in Ayurveda, Charaka Samhita, and Sushrita Samhita [11] Huge variety of phytochemicals like flavonoids, alkaloids, glycosides, rotenoids, steroids, lipids, triterpenoids, lignans, proteins, carbohydrates and glycoproteins etc have been reported from the herb [12]. The promising therapeutic effects of this plant include diuretic, hepatoprotective, anti-inflammatory, anti-cancer, anti-fibrinolytic, immuno-modulatory, anti-diabetic, immuno-suppressive, analgesic, anti-lymphoproliferative and used for the treatment of TB $[15,17,22]$.

The aim of this study is to develop a herbal tea formulation that possess high nutritive value and also to evaluate this herbal formulation by performing nutritional, sensory and phytochemical analysis.

\section{MATERIALS AND METHODS}

\section{A. Chemicals}

methanol, ethanol, ferric chloride, TPTZ, acetate buffer, hydrochloric acid, quercetin, sodium nitrite, $\mathrm{AlCl}_{3}$, sodium hydroxide, FC reagent, sodium carbonate, catechol, tannic acid, formic acid, theophylline, acetic acid, SPI solution.

\section{B. Sample collection and Extraction}

\section{Sample collection:}

Wedeliachinensis leaves and Boerhaaviadiffusa root powder were collected from an FSSAI approved herbal powder manufacturer from Coimbatore, Tamil Nadu. All herbs were stored in sealed container for further use. The samples were labeled as the Wedeliachinensis leaves (WC), Boerhaaviadiffusa (BD) and Tea formulation mix (TF MIX).

\section{Sample extraction:}

About $20 \mathrm{~g}$ of powdered TF MIX of these herbs was extracted with $150 \mathrm{ml}$ of distilled water. Then it is allowed to evaporate in open air to obtain aqueous extracts. 


\section{Nutritional analysis}

Determination of Moisture content

The moisture content of the TF MIX formulation was measured based on AACC method. Two gramsof formulation powder was placed over a weighed petri plate and dried using hot air oven at $120^{\circ} \mathrm{C}$ for 2 hours. After drying the petri plate weight was taken and the contents were cooled and then petri plate was re-weighed. The drop in the weight was calculated as percentage of moisture content.

Moisture content $(\%)=[(\mathrm{W} 1-\mathrm{W} 2) / \mathrm{W} 1] \times 100$

$\mathrm{W} 1=$ Weight $(\mathrm{g})$ of Sample before drying.

$\mathrm{W} 2=$ Weight $(\mathrm{g})$ of Sample after drying.

Determination of Ash content

The ash content of the TF MIX formulation was quantified, explained by AACC method. Twograms of theformulation powder was placed in a pre weighed crucible and then the incineration process undertakes in a muffle furnace at $420^{\circ} \mathrm{C}$ for 5 hours and then crucible was cooled and then weighed.

Ash $(\%)=[$ Weight of ash / Weight of Sample $] \times 100$ Determination of mineral composition

Inductively coupled plasma Mass spectrometry (ICP-MS), is used to analyze the composition of minerals in the sample.

\section{Phytochemical analysis}

Estimation of flavanoids (Shirazhi et al., 2014)

Samples were dissolved in their respective solvents $(1 \mathrm{mg} / \mathrm{ml})$ to serve as stock. $25 \mu \mathrm{l}$ of the formulation mix was taken and made up to $2.5 \mathrm{ml}$ with distilled water. To the formulation mix $75 \mu$ l of $5 \%$ sodium nitrite solution was added and incubated at room temperature for 5 minutes. After incubation $150 \mu \mathrm{l}$ of $10 \% \mathrm{AlCl}_{3}$ was added and incubated at room temperature for 6 minutes. $0.5 \mathrm{ml}$ of $1 \mathrm{M}$ sodium hydroxide was added and the colored complex formed was read at $510 \mathrm{~nm}$. Quercetin standard was used to prepare a calibration curve. The results were denoted as mg quercetin equivalents / g extract.

Estimation of Total phenol content (Siddiqui et al., 2017)

Sample was prepared by dissolving the extracts in their respective solvents $(1 \mathrm{mg} / \mathrm{ml})$. $0.1 \mathrm{ml}$ of the sample was taken and made up to $2 \mathrm{ml}$ with distilled water. $0.5 \mathrm{ml}$ of FC reagent was added and the tubes were incubated for 3 minutes. After the incubation period, $2 \mathrm{ml}$ of sodium carbonate was added and the tubes were kept in water bath for one minute at $50^{\circ} \mathrm{C}$. Then the absorbance of the colored complex formed was read at $650 \mathrm{~nm}$. Catechol was used as standard to draw the calibration curve. The results were denoted as catechol equivalents / g extract.

\section{Estimation of Tannins}

$0.2 \mathrm{ml}$ of the samples dissolved in their corresponding solvents were taken $(1 \mathrm{mg} / \mathrm{ml}) .0 .25 \mathrm{ml}$ of sodium carbonate solution was added to all the samples and $0.2 \mathrm{ml}$ of distilled was taken as blank. All the tubes were made up to $5 \mathrm{ml}$ with distilled water and incubated at room temperature for 90 minutes. The absorbance was read at $260 \mathrm{~nm}$. Tannic acid standard was used.
$0.5 \mathrm{ml}$ of the sample was taken and $4 \mathrm{ml}$ of formic acid was added and the absorbance was read at $530 \mathrm{~nm}$.

Anthocyanin content (mg/ $100 \mathrm{~g}$ of dry matter)

$=(\mathrm{A} \times \mathrm{MW} \times \mathrm{DF} \times 1000) /(\varepsilon \times 1)$

Where $\mathrm{A}=$ Absorbance

$\mathrm{DF}=$ Dilution factor

$\mathrm{MW}=$ Molecular weight of

cyaniding-3-glucoside chloride

(C21H21ClO11. 449.2)

$\mathrm{W}=$ Weight of the sample

$\varepsilon=$ Molar absorptivity (26.900)

Estimation of Alkaloids

$1.5 \mathrm{ml}$ of each sample was taken in boiling tubes and $1 \mathrm{ml}$ of $0.01 \mathrm{M}$ SPI solution and $0.5 \mathrm{ml} 0.1 \mathrm{M}$ acetic acid solution was added. $10 \mathrm{ml}$ of distilled water was added to all the boiling tubes and was kept in the boiling water bath for 10 minutes. After incubation, $2 \mathrm{ml}$ of the $0.01 \mathrm{M} \mathrm{MBTH}$ solution was added to all the tubes and kept in the boiling water bath for 2 minutes. The tubes were then cooled and made up to $25 \mathrm{ml}$ with distilled water. The complex formed was read at 630 $\mathrm{nm}$. Theophylline was used as a standard at a concentration of $1 \mathrm{mg} / \mathrm{ml}$. It was prepared by dissolving $10 \mathrm{mg}$ of theophylline in $20 \mathrm{ml}$ of methanol and then it was made upto $100 \mathrm{ml}$ with distilled water. The results were expressed as $\mathrm{mg}$ theophylline equivalents / g extract.

\section{E. Sensory analysis}

Selection of panelists

Twenty-five (25) panelists were recruited from Kumaraguru College of Technology campus for the acceptance tests. Panelists were mostly students aged between 18 and 26 years with few college staff.

About $30 \mathrm{ml}$ of each herbal infusion was served in a $50 \mathrm{ml}$ transparent glass cup. One sample was served at a time. Panelists were discouraged from conferring among one another during the analyses. The herbal infusions were approximately around $70{ }^{\circ} \mathrm{C}$ at the time of tasting.

The panelists were instructed to score their acceptance for 6 attributes of the infusions: colour, aroma, flavor, aftertaste, astringency and overall acceptability. The panelists scored their acceptance of the attributes using a 9-point hedonic scale with 1 meaning 'dislike extremely' and ' 9 ' meaning 'like extremely'.

\section{RESUlt AND DiscuSSION}

\section{Nutritional analysis}

Determination of Moisture content

Moisture content affects the food products stability and storage, etc. The moisture content was calculated for TF MIX which is reported in Table I. 
Table I: Moisture content estimation for TF MIX

\begin{tabular}{|l|l|}
\hline $\begin{array}{l}\text { Moisture } \\
\text { content \% }\end{array}$ & $2.66 \%$ \\
\hline
\end{tabular}

The moisture content value for tisanes should be less than $11 \%$ (Kirk and Sawyer, 1997). If the value is above the prescribed limit, the tea formulation will be liable to mould infestation. As the value is below the prescribed level, the shelf life of the product is unaffected by the moisture content.

\section{Determination of Ash content}

Ash content analysis is another important parameter, because it also directly influences thestability, nutritional content of the food and its storage, etc. Ash represents the inorganic residue that remainswhen the water and organic matter is removed by heating, which indicates the measure of the total amount of minerals present in a food. The ash content was calculated for TF MIX which is reported in Table II.

Table II: Ash content estimation for TF MIX

\begin{tabular}{|l|l|}
\hline Ash content & $10.95 \%$ \\
\hline
\end{tabular}

The ash content value for tisanes should be between in the range of $4 \%$ to $14 \%$.

\section{Determination of mineral composition}

The quantity of minerals present in the TF MIX is as tabulated in the Table III. An appreciable amount of sodium was present in TF MIX, which can play a key function in maintaining the loss of sodium due to diuretic action of the herbs, whereas magnesium has numerous health utilities including mediation of nerve impulses, regulation of body temperature,detoxification, production of energy, cardiac disorders and the growth of strong bones and teeth (Nordin et al., 1990). Another mineral is aluminium, which was present in high amount, helps in increasing immunity. High potassium helps in treating kidney disorders, lowering blood pressure, increasing water flow in body and mainly acting as an anti-diabetic. The other trace minerals such as chromium, manganese, iron, zinc, copper and molybdenum were present in little amounts, which will exhibit their own therapeutic potentials ranging from boosting immunity, detoxification to being anti-carcinogenic and improving brain function (Liao et al., 1998).

Table III:Estimation of Mineral content for TF MIX

\begin{tabular}{|l|l|l|}
\hline S.No & Analyte & $\begin{array}{l}\text { Concentration } \\
\text { (ppm) }\end{array}$ \\
\hline 1 & $\mathrm{Na}$ & 4501.99 \\
\hline 2 & $\mathrm{Mg}$ & 17210.69 \\
\hline 3 & $\mathrm{Al}$ & 4539.98 \\
\hline 4 & $\mathrm{~K}$ & 109181.22 \\
\hline
\end{tabular}

\begin{tabular}{|l|l|l|}
\hline 5 & $\mathrm{Cr}$ & 0.0014 \\
\hline 6 & $\mathrm{Mn}$ & 0.0409 \\
\hline 7 & $\mathrm{Fe}$ & 0.3793 \\
\hline 8 & $\mathrm{Cu}$ & 0.0024 \\
\hline 9 & $\mathrm{Zn}$ & 0.0041 \\
\hline 10 & $\mathrm{Mo}$ & 0.35 \\
\hline
\end{tabular}

The complete absence of toxic heavy metals selenium, arsenic, lead and cadmium makes this product, free of any toxicity and a safely consumable one. The presence of fair amount of mineral content makes this product a potent nutraceutical.

\section{Phytochemical analysis}

Table IV represents the contents of flavonoids, total phenol, tannins, alkaloids and anthocyanins in aqueous extract of TF MIX.

Phenolic compounds depict antioxidant and can act as scavengers of free radicals. These activities in vivo may slow down the ageing processes as well as protect the human body against against diseases such as atherosclerosis, coronary diseases and cancer (Lee et al., 1993). Flavonoids, is one of the polyphenolic compounds, that is widely present in vegetables and fruits. Multiple positive health effects have been reported such as anti-cancer, anti-inflammatory effects, anti-viral and to minimize the risk of cardiovascular diseases (Vessal et al., 2003). These activities are generally associated with antioxidant properties of flavonoids. The number of flavonoid derivatives is more than 4000 and their antioxidant properties are very different. Alkaloids are a class of nonnutritive phytochemical compounds that are synthesized as secondary metabolites by the plant cells (Cody et al., 1986). They fight against free radicals and are capable of quenching their activity. The presence of phytoconstituents like flavonoids, alkaloids and others was estimated by various phytochemical assays.

The presence of these photochemical simply attributes to the antimicrobial and antioxidant activities of the tea formulation (Blytt et al., 1988). Flavonoids, major crusaders in the prevention of cancer, also possess antiviral and anti-bacterial properties.

Alkaloids are usually synthesized as secondary metabolites in the plants and thus exhibit various health benefits. Total phenols are involved in the delaying the process of ageing. Tannins and anthocyanins also contribute to antioxidant properties of plant extracts. Anthocyanins are representative of pigments present in colored fruits and flowers. Due to high consumption of anthocyanins, it would be of great interest to find out the additional biological benefits related to these compounds (Dillard et al., 2000). 
Table IV: Quantification of polyphenolic compounds in TF

\begin{tabular}{|l|l|l|}
\multicolumn{2}{c}{ MIX } \\
$\begin{array}{l}\text { Phytochemical } \\
\text { tested }\end{array}$ & $\begin{array}{l}\text { Value (mean } \\
\pm \text { SD) of } \\
\text { three } \\
\text { replicates }\end{array}$ & Units \\
\hline Total Phenols & $3.85 \pm 0.04$ & $\begin{array}{l}\text { Catechol equivalents (mg } \\
\text { CE/g sample) }\end{array}$ \\
\hline Flavanoids & $1.6 \pm 0.033$ & $\begin{array}{l}\text { Quercetin equivalents (mg } \\
\text { QE/g sample) }\end{array}$ \\
\hline & $35.72 \pm 0.01$ & $\begin{array}{l}\text { Tannic acid equivalents (mg } \\
\text { TAE/g sample) }\end{array}$ \\
\hline Tannins & & $\begin{array}{l}\text { Cyanadin-3-glucoside } \\
\text { equivalents (mg C3gE/100g } \\
\text { sample) }\end{array}$ \\
\hline Anthocyanins & $203.33 \pm 0.03$ & $\begin{array}{l}\text { Theophylline equivalents } \\
\text { (mg TE/g sample) }\end{array}$ \\
\hline & &
\end{tabular}

\begin{tabular}{|c|c|c|c|}
\hline Hexadecanoic acid & $57-10-3$ & 20.575 & 3.201 \\
\hline $\begin{array}{c}\text { Estra-1,3,5(10)-trien-17- } \\
\text { one, } 2- \\
\text { [(trimethylsilyl)amino]-3- } \\
\text { [(trimethylsilyl)oxy]- }\end{array}$ & $77883-26-2$ & 25.907 & 2.139 \\
\hline $\begin{array}{l}\text { 1,5-Dimethoxy-2,4-bis(3- } \\
\text { Methylphthalidyl)Benzol }\end{array}$ & $64042-52-0$ & 28.57 & 1.567 \\
\hline $\begin{array}{l}\text { Dimethyl 2,3-bis(1,3- } \\
\text { dimethylindol-2- } \\
\text { yl)fumarate }\end{array}$ & $72206-09-8$ & 28.57 & 1.567 \\
\hline $\begin{array}{c}1,8-\operatorname{Bis}(3,4- \\
\text { dicyanophenyl)anthracene }\end{array}$ & $122504-53-4$ & 28.57 & 1.567 \\
\hline $\begin{array}{l}\text { 2-Butenoic acid, } 2- \\
\text { methyl- }\end{array}$ & $77573-09-2$ & 41.881 & 0.116 \\
\hline $\begin{array}{c}\text { n-Butyryl-3- } \\
\text { demethylthiocolchicine }\end{array}$ & $123643-58-3$ & 41.881 & 0.116 \\
\hline $\begin{array}{l}\text { Benzeneacetic acid, } 3,4- \\
\text { dimethoxy-, trimethylsilyl } \\
\text { ester }\end{array}$ & $27750-60-3$ & 42.144 & 0.162 \\
\hline $\begin{array}{c}\text { 4-Cyanonaphtho }[1,2- \\
\text { b]thiophene }\end{array}$ & $107971-16-4$ & 44.343 & 0.996 \\
\hline
\end{tabular}

\section{GC-MS analysis}

The secondary metabolites in the TF MIX were determined by GC-MS. Analysis of aqueous extract of TF MIX resulted in detection of phytochemicals and common fatty acid. The details of some noted compounds are tabluated in Table V. The main compounds were myo-inositol, which is the most common form of inositol, is a sugar alcohol found in nearly all plants and animals (Downes and Macphee., 1990). Myo-inositol decreases high blood pressure and sugar levels. Myoinositol has antioxidant, anti-inflammatory, and immune-enhancing properties.

Hexadecanoic acidpossesses mild antioxidant and anti-atherosclerotic properties, which also add texture and mouth, feel to processed foods (Mancini et al., 2015).

The presence of neronine, an alkaloid imparts antimicrobial and antioxidant activities. Butenoic acid has numerous beneficial effects in humans on energy homeostasis and related diseases such as diabetes and obesity and also it has pronounced antimicrobial and anticarcinogenic effects.

Benzene acetic acid helps in relaxing mood and treating brain disorders. Presence of various other compounds such as 4, 5 - cyclopenteno-1, 2-diazine, p - hydroxystyrene, cyclohexasiloxane increases the health benefits of the formulation.

Table V:TF MIX extracts GCMS profiling

\begin{tabular}{|l|l|l|l|}
\hline Compound Name & Cas \# & RT & $\begin{array}{l}\% \\
\text { Area }\end{array}$ \\
\hline $\begin{array}{l}\text { 4,5-cyclopenteno-1,2-dia } \\
\text { zine }\end{array}$ & $6250-96-0$ & 6.334 & 2.199 \\
\hline $\begin{array}{l}\text { N-Benzyl-2-phenethyla } \\
\text { mine }\end{array}$ & $3647-71-0$ & 6.334 & 2.199 \\
\hline $\begin{array}{l}\text { p-hydroxystyrene } \\
\text { Cyclohexasiloxane, } \\
\text { dodecamethyl }\end{array}$ & $2628-17-3$ & 6.334 & 2.199 \\
\hline $\begin{array}{l}\text { 3-Butoxy-1,1,1,7,7,7-he } \\
\text { xamethyl-3,5,5-tris(trim } \\
\text { ethylsiloxy)tetrasiloxane }\end{array}$ & $72439-84-0$ & 13.731 & 0.86 \\
\hline $\begin{array}{l}\text { Myo-Inositol, } \\
\text { 4-C-methyl- }\end{array}$ & $472-95-7$ & 11.475 & 1.01 \\
\hline \begin{tabular}{l} 
Neronine \\
\hline
\end{tabular} & $1167-58-4$ & 16.482 & 1.935 \\
\hline
\end{tabular}

Sensory analysis

Sensory evaluation of the herbal infusion was performed for overall acceptance (colour, aroma, Flavor, astringency and after taste) by 20 members on the basis of 9-point Hedonic scale.

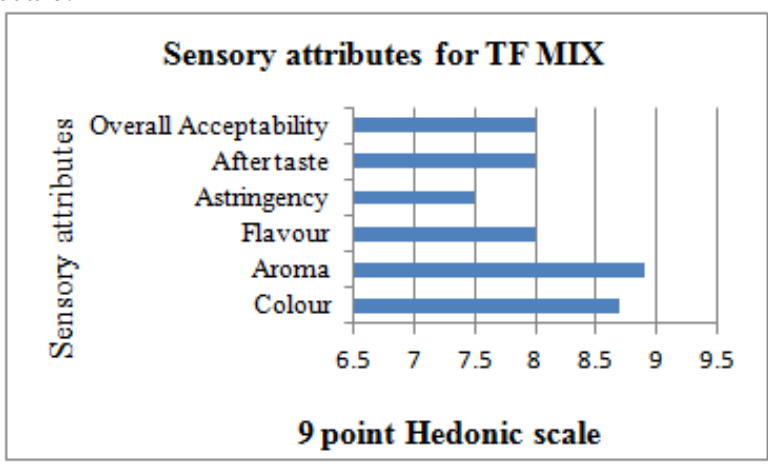

Figure 1: Sensorial attributes of formulated herbal tea

From the above sensory data the average of overall acceptability was around 8 which means 'like very much' as per the 9 point hedonic scale. Thus, the sensory attributes makes the herbal tea eligible for a commercial consumable with high scores from evaluators for its colour and aroma. The astringency created by it was least liked by the evaluators.

\section{CONCLUSION}

The results of the nutritional, phytochemical profile proved that the formulation mixture of herbs Wedeliachinensis and Boerhaaviadiffusa roots is an excellent source of nutraceuticals with high therapeutical importance. Enormous health benefits 
highlighted in the polyherbal formulation shape it as anideal physical and mental health rejuvenator. The low economy community can benefit best out of this, to improve their health. Hence, the above herbal infusion can be used as a better alternative to flavored teas which can render health gains too.

\section{ACKNOWLEDGMENT}

The authors acknowledge Department of Biotechnology and Re forum (Research Cell) of KCT for providing essential facilities and funding to perform the research.

\section{REFERENCES}

1. Banu, R., \& Nagarajan, N. (2014). TLC and HPTLC fingerprinting of leaf extracts of Wedelia chinensis (Osbeck) Merrill. Journal of Pharmacognosy and Phytochemistry, 2(6).

2. Benzie, I. F., \& Strain, J. J. (1996). The ferric reducing ability of plasma (FRAP) as a measure of "antioxidant power": the FRAP assay. Analytical biochemistry, 239(1), 70-76.

3. Blytt HJ, Guscar TK, Butler LG (1988). Antinutritional effects and ecological significance of dietary condensed tannins may not be due to binding and inhibiting digestive enzymes. Journal of Chemical Ecology, 14:1455-1465.

4. Bumbrah, G. S., Krishan, K., Kanchan, T., Sharma, M., \& Sodhi, G. S. (2012). Phosphide poisoning: a review of literature. Forensic science international, 214(1-3), 1-6.

5. Carmona, M. D., Llorach, R., Obon, C., \& Rivera, D. (2005). "Zahraa", a Unani multicomponent herbal tea widely consumed in Syria: Components of drug mixtures and alleged medicinal properties. Journal of ethnopharmacology, 102(3), 344-350.

6. Cody V, Middleton E, Harborne JB (1986). Plant flavonoids in biology and medicine: Biochemical, pharmacological and structure activity relationship. Alan Res Liss Inc, 521-536.

7. Das, M. P., Rebecca, L. J., \& Sharmila, S. (2013). Evaluation of antibacterial and antifungal efficacy of Wedelia chinensis leaf extracts. Journal of Chemical and Pharmaceutical Research, 5(2), 265-9.

8. Dillard CJ, German JB (2000). Phytochemicals: Nutraceuticals and Human Health. Journal of Science Food Agricultural, 80(12):1744-1756.

9. Downes, C. P., \& Macphee, C. H. (1990). myo-Inositol metabolites as cellular signals. The FEBS Journal, 193(1), 1-18.

10. Kirk, R.S. and R. Sawyer, 1997. Pearson's Composition and Analysis of Foods. 9th Edn., Longman, Singapore, pp: 238-239.

11. Koul, S., Pandurangan, A., \& Khosa, R. L. (2012). Wedelia chinenis (Asteraceae)-an overview. Asian Pacific Journal of Tropical Biomedicine, 2(2), S1169-S1175.

12. Krishnaiah, D., Devi, T., Bono, A., \& Sarbatly, R. (2009). Studies on phytochemical constituents of six Malaysian medicinal plants. Journal of medicinal plants research, 3(2), 067-072.

13. Kumari, A., \& Bhatnagar, S. (2016). Phytochemical Analysis and Biological Evaluation of Leaf Extracts of Wedelia Chinensis. Pharm Pharmacol Int J, 4(7), 00102.

14. Lee SJ, Son KH, Chang HW (1993). Anti-inflammatory activity of naturally occurring flavone and flavonol glycosides. Archives Pharmacal Research, 25-28.

15. Mahesh, A. R., Kumar, H., Ranganath, M. K., \& Devkar, R. A. (2012). Detail study on Boerhavia Diffusa plant for its medicinal importance-a review. Res J Pharm Sci, 1, 28-36.

16. Mancini, A., Imperlini, E., Nigro, E., Montagnese, C., Daniele, A., Orrù, S., \& Buono, P. (2015). Biological and nutritional properties of palm oil and palmitic acid: effects on health. Molecules, 20(9), 17339-17361.

17. Manjamalai, A., Jiflin, G. J., \& Grace, V. M. (2012). Study on the effect of essential oil of Wedelia chinensis (Osbeck) against microbes and inflammation. Asian J Pharm Clin Res, 5, 155-63.

18. Murti, K., Panchal, M. A., \& Lambole, V. (2010). Pharmacological properties of Boerhaavia diffusa-a review. Int $J$ Pharm Sci Rev Res, 5(2), 107-110.

19. Namdev, P., \& Gupta, R. K. (2015). Herbal green tea formulation using Withania somnifera stems, Terminalia arjuna bark, Cinnamon bark and Tinospora cordifolia stems and nutritional \& phytochemical analysis. Journal of Pharmacognosy and Phytochemistry, 4(2).

20. Nayak, P., \& Thirunavoukkarasu, M. (2016). A review of the plant Boerhaavia diffusa: its chemistry, pharmacology and therapeutical potential.

21. Nikhila, G. S., Sangeetha, G., Preetha, T. S., \& Swapna, T. S. (2016) GC-MS analysis of phytochemical compounds presents in the rhizome of Gloriosa superba L. Journal of Pharmacognosy and Phytochemistry, 5(5), 17.

22. Nomani, I., Mazumder, A., \& Chakraborthy, G. S. (2013). Wedelia chinensis (Asteraceae)-An Overview Of A Potent Medicinal Herb. Int J PharmTech Res, 5(3), 957-964.

23. Nordin BE, Heaney RP. Calcium Supplementation of the Diet Justified by Present Evidence. British Medical Journal. 1990; 300(6731):1056-1060. 45

24. Puodziūniene, G., Janulis, V., Milasius, A., \& Budnikas, V. (2005) Development of cough-relieving herbal teas. Medicina (Kaunas, Lithuania), 41(6), 500-505.

25. Sharma, P., Bhardwaj, R., Yadav, A., \& Sharma, R. A. (2014) Antioxidant Properties of Methanolic Extracts of Boerhavia diffusa. Research Journal of Phytochemistry, 8(3), 119-126.

26. Shirazi, O. U., Khattak, M. A. K., Shukri, N. A. M., \& Nasyriq, M. N. (2014). Determination of total phenolic, flavonoid content and free radical scavenging activities of common herbs and spices. Journal of Pharmacognosy and Phytochemistry, 3(3), 104-108.

27. Siddiqui, N., Rauf, A., Latif, A., \& Mahmood, Z. (2017) Spectrophotometric determination of the total phenolic content, spectral and fluorescence study of the herbal Unani drug Gul-e-Zoofa (Nepeta bracteata Benth). Journal of Taibah University Medical Sciences, 12(4), 360-363.

28. Sun, F., \& Yu, J. (2000). The effect of a special herbal tea on obesity and anovulation in Androgen-sterilized rats. Proceedings of the Society for Experimental Biology and Medicine, 223(3), 295-301.

29. Sundararajan, R., Bharampuram, A., \& Koduru, R. (2014). A review on phytoconstituents for nephroprotective activity. Pharmacophore, 5(1).

30. Toda, S. (2011). Polyphenol content and antioxidant effects in herb teas. Chinese Medicine, 2(01), 29.

31. Vessal M, Hemmati M, Vasei M (2003). Antidiabetic effects of quercetin in streptozocin induced diabetic rats. Comparative Biochemistry Physiology, 357-364.

32. Vicentini, V. E. P., Camparoto, M. L., Teixeira, R. O., \& Mantovani, M. S. (2001). Averrhoa carambola L., Syzygium cumini (L.) Skeels and Cissus sicyoides L.: medicinal herbal tea effects on vegetal and animal test systems. Acta Scientiarum, 23(2), 593-598.Science, 1989.

\section{AUTHORS PROFILE}

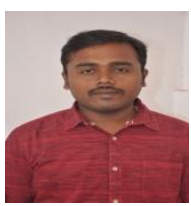

S J Kabilan, completed his B.Tech (Biotechnology) at Kalasalingam University and M.Tech (Biotechnology) at Kumaraguru College of Technology (Affiliated to Anna University). Both the Degrees completed with First class with Distinction. Also, pursuing $\mathrm{PhD}$ in the area of Herbal Drug Research.

Currently Employment: Assistant Professor, Department of Biotechnology, School of Bio and Chemical Engineering, Kalasalingam Academy of Research and Education, Tamilnadu, India.

Previous Publications: Kabilan, M. S. (2018). Antioxidant and anti-inflammatory properties of G-immune plus: A polyherbal formulation. International Journal of Green Pharmacy (IJGP), 12(03).

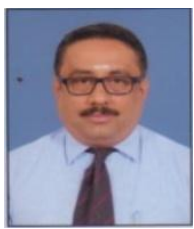

Dr. R. Baskar, $\mathrm{PhD}$ in Medical Biochemistry. Currently working as Associate professor at Kumaraguru college of Technology, Coimbatore, Tamilnadu, India.

Memberships:

Life Member in Indian Society for Technical Education Life Member in National Society for Ethnopharmacology

Achievements:

1. INSA Summer Fellowship award during 2012 to work in the Laboratory of Plant-Microbe Interaction, School of Botany, University of Hyderabad on "Plant Growth Promoting Rhizobacteria".

2. Reviewer in National and International Journals 
Herbal Tea Formulation for Health Rejenuvation: Nutritional, Physicochemical and Sensory Analysis

3. Currently Academic Editor in Biotechnology Journal International.

4. No. of citations : $792 ; \mathrm{h}$ index : $12 ; \mathrm{i} 10$ index : 16

Recent Publications:

- Baskar,R., Akshaya, S.B., Akshitha, R., Dhilip Kumar, G. , Poorani, G. (2018).Evaluation of antioxidant and phytochemical activity in solvent extracts of Delonix regia.International Journal of Green Pharmacy, Volume 12(3), July-September issue, S607-S616.

- Baskar, R., Sweatha, S., Karunambika, R., G.Ramya, R.Shanthi (2017).

Influence of methionine on ergothineine content and antioxidant activity of Pleurotus platypus.Asian Journal of Microbiology, Biochemistry and Environmental Sciences, Volume 19 (Supplementary issue), S34-S38.

- $\quad$ Gurumallesh, P., Alagu, K., Ramakrishnan, B. and Muthusamy, S (2019).A systematic reconsideration on proteases.International Journal of Biological Macromolecules, 128, 254-267 (Impact Factor: 4.7)

- PooraniGurumallesh, Baskar Ramakrishnan and BhaarathiDhurai (2019). A novel metalloprotease from banana peel and its biochemical characterization. International Journal of Biological Macromolecules, 134, 527- 535 (Impact factor: 4.7)

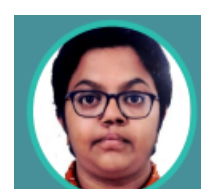

Poorani G completed her B.Tech (Biotechnology) at Tamil Nadu Agricultural University, Coimbatore and M.Tech Pharmaceutical Technology at SASTRA University, Thanjavur and currently pursuing Ph.D Kumaraguru College of Technology.

INTERNATIONAL $\frac{\text { Notable Publications: }}{\text { JOURNAL }}$ OF BIOLOGICAL MACROMOLECULES (2019) IF 4.78 A novel metalloprotease from banana peel and its biochemical characterization

MATERIAL SCIENCE AND ENGINEERING C (2019) IF 5.08 Biological synergy of greener gold nanoparticles by using Coleus aromaticus leaf extract

INTERNATIONAL JOURNAL OF BIOLOGICAL MACROMOLECULES (2019) IF 4.78 A systematic reconsideration on proteases

PROCESS BIOCHEMISTRY (2019) IF 2.88 Green synthesis of anisotropic silver nanoparticles from the aqueous leaf extract of Dodonaeaviscosa with their Antibacterial and Anticancer activities

JOURNAL OF PHOTOCHEMISTRY AND PHOTOBIOLOGY B: BIOLOGY (2018) IF 4.06 Improved Conductivity and Antibacterial activity of poly (2- aminothiophenol) - silver nanocomposite against human pathogens

JOURNAL OF MICROENCAPSULATION (2016) IF 2.04 Formulation, characterization, in vitro and in vivo evaluation of castor oil based self-nano emulsifying levosulpiride delivery systems 